\title{
The relationship between moral intervention strategies and the stigmatisation of people living with HIV - A Christian perspective
}

\begin{tabular}{|c|c|}
\hline \multicolumn{2}{|c|}{$\begin{array}{l}\text { Authors: } \\
\text { Izak J. van der Walt }{ }^{1} \\
\text { Jacobus M. Vorster }\end{array}$} \\
\hline \multicolumn{2}{|c|}{$\begin{array}{l}\text { Affiliations: } \\
{ }^{1} \text { Faculty of Natural Sciences, } \\
\text { North-West University, } \\
\text { Potchefstroom, South Africa }\end{array}$} \\
\hline \multicolumn{2}{|c|}{$\begin{array}{l}\text { 'Faculty of Theology, } \\
\text { North-West University, } \\
\text { Potchefstroom, South Africa }\end{array}$} \\
\hline \multicolumn{2}{|c|}{$\begin{array}{l}\text { Corresponding author: } \\
\text { Izak van der Walt, } \\
\text { kobus.vanderwalt@nwu.ac. } \\
\text { za }\end{array}$} \\
\hline \multicolumn{2}{|c|}{$\begin{array}{l}\text { Dates: } \\
\text { Received: } 24 \text { Feb. } 2016 \\
\text { Accepted: } 06 \text { June } 2016 \\
\text { Published: } 19 \text { Aug. } 2016\end{array}$} \\
\hline \multicolumn{2}{|c|}{$\begin{array}{l}\text { How to cite this article: } \\
\text { Van der Walt, I.J. \& Vorster, } \\
\text { J.M., 2016, 'The relationship } \\
\text { between moral intervention } \\
\text { strategies and the } \\
\text { stigmatisation of people } \\
\text { living with HIV - A Christian } \\
\text { perspective', HTS Teologiese } \\
\text { Studies/Theological Studies } \\
\text { 72(3), a3384. http://dx.doi. } \\
\text { org/10.4102/hts.v72i3.3384 }\end{array}$} \\
\hline \multicolumn{2}{|c|}{$\begin{array}{l}\text { Copyright: } \\
\text { ( ) 2016. The Author } \\
\text { Licensee: AOSIS. Thi } \\
\text { is licensed under the } \\
\text { Creative Commons } \\
\text { Attribution License. }\end{array}$} \\
\hline \multicolumn{2}{|l|}{ Read online: } \\
\hline 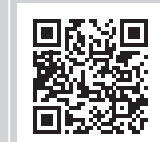 & $\begin{array}{l}\text { Scan this QR } \\
\text { code with your } \\
\text { smart phone or } \\
\text { mobile device } \\
\text { to read online. }\end{array}$ \\
\hline
\end{tabular}

One of the ways in which sexual transmission of AIDS is addressed is through moral interventions by organisations affiliated with Christian churches. However, this approach has been heavily criticised in recent literature, implying that moral interventions by churchaffiliated organisations generally lead to stigmatisation which is one of the major obstacles to their involvement in HIV prevention. This article explores the origin of this accusation and discusses the Christian-ethical aspects related to HIV or AIDS. The conclusion is that the fact that churches take the Word of God and Christian morality as point of departure in HIV or AIDS intervention programmes does not imply that people who transgressed religious moral teachings may be condemned. On the contrary, the church preaches Christian forgiveness, mercy and empathy. Churches and organisations affiliated with churches should therefore be regarded as valuable partners in the fight against AIDS, for while propagating a normative lifestyle, they also preach love, compassion and support for people living with HIV.

\section{Introduction}

According to Sidebe (2015:4), various recent UNAIDS reports demonstrate remarkable success in addressing the global AIDS epidemic. Since 2001, new HIV infections have fallen by 38\%, and new infections among children have fallen by 58\%, dropping below 200000 in 21 highly affected countries in Africa for the first time since the pandemic began. UNAIDS wants to step up HIV treatment through '90-90-90' targets (90\% of people living with HIV knowing their HIV status, $90 \%$ of people living with HIV who know their status on antiretroviral treatment, and $90 \%$ of people on treatment having suppressed viral loads), as well as reaching ambitious prevention and stigma reduction targets by 2020 (Sidebe 2015:4). In order for UNAIDS to achieve their goals, 10 targets have been formulated of which the first target is to reduce sexual transmission of HIV by $50 \%$ by 2015 , and the eighth target is to eliminate stigmatisation and discrimination towards people living with HIV (UNAIDS 2015:95).

South Africa has one of the highest infection rates in the world. The estimated overall HIV prevalence rate in 2015 was approximately 11.2\% of the total South African population, which equals approximately 6.19 million people. For adults aged $15-49$ years, an estimated $16.6 \%$ of the population is HIV positive (Statistics SA 2015:7). Oosthuizen (2001:436) projected more than a decade ago that by the end of 2015, an estimated 12.5 million South Africans will have died of AIDS. Although the rate of infections is showing a decline (Statistics SA 2015:5), the situation still requires urgent and sustained intervention programmes.

Intervention programmes can be medically or behaviourally based. Behaviourally based programmes strive to change human behaviour in order to reduce the risk of infection by increasing knowledge about the transmission of the virus, as well as by attempting to delay the age at which young people become sexually active. Such programmes furthermore discourage premarital or extramarital sexual activity, and strive to increase the prevalence of HIV prevention strategies such as condom use and knowing one's HIV status, as well as eliminate gender inequalities, stigma and discrimination (UNAIDS 2015:28).

One of the behaviourally based ways in which sexual transmission of the HI virus is addressed is through moral interventions by organisations affiliated with Christian churches. However, this approach is heavily criticised in recent literature, implying that moral interventions by church-affiliated organisations generally lead to stigmatisation which is one of the major obstacles to their involvement in HIV prevention. Hershey (2015:3075) compares religious and secular non-governmental organisations (NGOs) that are active in developmental efforts (including reducing the spread of HIV) to investigate whether and how faith manifests in these 
organisations. In a study conducted in Kenya, she found that faith rarely emerges in the programs of Christian religious NGOs because of constraints by donor restrictions and a need for legitimacy that removes religious elements from the programs of religious NGOs. Furthermore, in a study conducted in Malawi on Christian and Muslim faith-based organisations (FBOs), Lindgren et al. (2013:234) found that the level of power and influence of the FBOs had no significant impact on the risk-taking behaviour of members, but that stigmatising attitudes of leaders have a negative effect on the willingness of other members to care for infected people.

Santelli, Speizer and Edelstein (2013:1) report that the abstinence-until-marriage (AUM) approach initially followed in the USA demonstrated limited efficacy in changing behaviour. Instead, it rather caused medically inaccurate information because of young people not being honest about their sexual behaviour, while simultaneously withholding lifesaving information about risk reduction-related behaviour because of the exclusive focus on abstinence. AUM also undermined efforts in various African countries to create integrated youth HIV prevention programmes. As a result, a paradigm shift to science-based intervention programmes is called for. Morgan, Green and Boesten (2014:313) state that the response to HIV or AIDS prevention and mitigation services in Africa provided by FBOs has been controversial, particularly with regard to HIV or AIDS prevention, exacerbated by FBO's rejection of condom use which negatively influences national HIV or AIDS prevention efforts. This view is supported by Campbell, Skovdal and Gibbs (2011:1204), stating that the church often perpetuates HIV- or AIDS-related stigma through moralistic attitudes and its reinforcement of conservative gender ideologies. Furthermore, Mash and Mash (2013:5) state that FBOs fail to be important role-players in HIV prevention because of the church's reluctance to openly discuss sexuality, stigmatisation, gender issues and the rejection of condoms. They further found that, contrary to first-world countries, religiosity does not seem to reduce risky sexual behaviour in Africa.

Smith et al. (2014:387) developed a 'stigma scale' that is suitable for a country such as South Africa with diverse culture groups. The majority of participants in the study of Smith et al. (2014:387) were female (69.5\%), Christian (86.7\%) and identified as African (83.3\%). The results of the survey demonstrated that shame, judgement and rejection are salient aspects of HIV stigma in South Africa. This perceived tendency towards 'faith-based condemnation' is confirmed by Mavhandu-Mudzusi and Sandy (2015:4), who found that religion-related stigma and discrimination were common at a rural-based university in South Africa, where Lesbian, gay, bisexual and transgender students were labelled as 'sinners', 'devils' and 'demon possessed'. Study participants reported attempts to convert their sexual orientation which involved the use of intervention in the form of prayers.

Mash and Mash (2013:6), although critical about the efficacy of faith-based interventions, concede that churches may have a positive impact on alcohol use and its associated risky behaviour. The influence of the church on sexual behaviour may also be associated with the degree of social engagement and control within the church culture. This is the view of Trinitapoli and Weinreb (2012:154) who, in their book Religion and AIDS in Africa, submit that religion's impact on AIDS has often been far more salutary than otherwise. They found that often-cited accusations about religious institutions and leaders promoting HIV-related stigma or withholding care from people living with AIDS on moral grounds simply do not hold. Eriksson et al. (2014:1670) report that $60.8 \%$ of South African youth appear to have internalised religious teachings regarding decisions about their sexual behaviour. However, South African churches still focus mainly on moral aspects of sexuality, while giving less information on sexuality and relationships. Thus, they fail to fully address the needs of young people, which must be met for successful HIV prevention.

The aforementioned discussion represents only a limited view on numerous publications which propose that Christian organisations seldom address aspects of human sexuality other than morals. The claim is that this omission is likely to result in stigmatisation because people living with HIV who were infected through sexual transmission are perceived to have transgressed moral religious teachings. This may explain why the youth seem to find it difficult to talk to a church leader about sexuality, as reported by Eriksson et al. (2014:1672) regarding South African youth, as well as by Paiva et al. (2010:286) regarding youth from Brazil. Both studies confirmed that although religious leaders thought they were open to discuss sexuality, the youth did not share this view and said that sexuality was a difficult subject to discuss with the church leaders.

\section{A Christian-ethical approach to HIV or AIDS}

The HIV or AIDS pandemic does not only infect individuals, but also society at large. Therefore, it is necessary to discuss HIV from the perspective of the ethics of human rights.

The first ethical issue at stake is whether the HIV pandemic should be seen as a state of emergency requiring extraordinary measures. States of emergency have been declared in various countries at various times in history for much lesser than this pandemic, such as natural disasters and political conflicts. The central theme of publications by scholars such as Van Niekerk (2003), Nattrass (2010), Chigwedere and Essex (2010), Goodson (2014) and Kalichman (2009) is that the HIV crisis in South Africa requires radical decisions.

In emergency situations, conflicts in ethical decisions and directives arise with regard to the right of the individual versus the interests of the community. This is also the case with the HIV pandemic in South Africa, where fundamental rights and obligations such as non-discrimination, equal protection, privacy, social security, being free from torture and cruel, inhuman or degrading treatment or punishment; and equality before the law are relevant (Vorster 2004:228). 
Secondly, statistics indicate that the treatment and prevention of HIV do not only pose a huge challenge to medical care, social resources, state finances and policies, but also confront the human rights debate with a serious moral dilemma. Important issues at stake are, amongst others, the stigmatisation of people living with HIV and discrimination against them as well as the consequent problems regarding the disclosure and notification of the infection (Vorster 2004:228).

Parmet and Jackson (1997:41) offer an interesting argument when they argue for viewing the pandemic not as a plague, but as a social problem confronting humanity similar to a host of other social problems. Regarding HIV, they propose a change from the 'plague' metaphor to the idea of a chronic disease. This revised social construction of HIV provide people with a better understanding and handling of the situation. When HIV is seen as one of many social problems humankind has to deal with, extreme positions may be avoided. On the one hand, the discrimination against HIV patients and the violation of their human rights would be reduced, whereas on the other hand the strong reaction against discrimination in the form of a radical protection of the rights of the individual might have been curbed.

However, to define HIV as 'just another social problem' as Parmet and Jackson (1997:41) did, does not clear away the moral dilemma surrounding the pandemic. Difficult decisions still have to be made in the field of human rights with regard to HIV, such as whether the HIV patient's right to privacy should be limited with regard to disclosing their status to a partner. If not, what about the health of the partner, and what will be the legal consequences if the partner becomes infected too? Should the person who infects a partner by withholding the information about their status be charged with homicide? The same argument applies to the relationship between people living with HIV and health workers, as well as in the 'maternal-foetal' conflict. Another extreme indication of the moral dilemma is the argument that it is better to concentrate on the prevention of infections rather than 'waste' effort and expense on the affected for which nothing can be done. Prevention should have preference above treatment (Venter et al. 2014:609).

The moral dilemma poses a huge challenge to Christian ethics, because it boils down to one particular problem, which is the phenomenon of stigmatisation of people living with HIV and subsequent discrimination against them. Why do people stigmatise sufferers of HIV? Why do we find discrimination in this field and not with other highly infectious diseases?

\section{Stigmatisation and discrimination}

People living with HIV are stigmatised in modern-day society and are therefore victims of all forms of discrimination in the workplace educational institutions and even in religious communities. The main reason for this reality is that HIV or AIDS is perceived to be the result of unacceptable sexual and moral behaviour (Beaulieu et al. 2014:2). In the 1980s, it was seen as the illness of homosexual individuals and drug addicts, and since then it has been looked upon as the illness of heterosexual people with a promiscuous lifestyle. In some African cultures, people living with HIV often face communitywide discrimination, public shame and humiliation and may even be cast from their families or communities (Williams 2014:146).

This stigmatisation and discrimination are the most inhibiting factors in the prevention and treatment of HIV or AIDS. A study by the World Council of Churches (1997:13) argue the stigmatisation of persons because of their social status, sexual orientation or addiction to drugs makes them even more vulnerable to risks, including the risk of infection. If people living with HIV feel excluded and are afraid of having their status revealed, they are less likely to seek care and counselling, to have access to health information and to cooperate with AIDS prevention programmes (World Council of Churches 1997:13).

One reason for the stigmatisation of people living with HIV is that many such people are coming from communities which are already marginalised and the victims of discrimination (Vorster 2004:231). Statistics prove that people such as homosexual individuals, drug addicts, the homeless, the poor, the jobless and prostitutes are more prone to HIV infection (Campbell 2004:197). In the USA it was these already out-cast groups who initially contracted the infection, who then had to bear the burden of the stigmatisation attached to their social group.

The roots of stigmatisation can be found in the way sexuality was perceived throughout the history of moral thinking. The historical view of sexuality as something impure, something of a lower order over and against the superiority of the 'spiritual things', has a lot to do with this perception. Within the Western world this idea of the inferiority of human sexuality can be traced back to some schools in Greek philosophy, especially Neo-platonism and Gnosticism, with its separation of the spiritual 'higher' realm and the material 'lower realm'. Sexuality was seen as part of the latter. This dichotomy between the sacral and material became part of the Gnostic worldview during the time of the early development of Christianity. According to this worldview two parallel worlds exist: the original, divine world of the spirit and the spiritual dimension of life and the inferior material world. The first world is called the Fullness (pleroma) and the latter the Void (kenoma) (Walker 1992:63). Therefore Gnostic ethics was marked by hostility towards the body and striving to escape from the world. Sexuality, being part of the incomplete material world, was regarded as a degraded unholy part of life, which should be sacrificed in favour of an ascetic lifestyle (Nagel 2001:419). Even the influential Christian theologian Augustine regarded sexual intercourse as something tainted by concupiscence and the lingering effects of original sin (McCormick \& Connors 2002:149). A couple can avoid this sin only when they engage in sex solely for the purpose of procreation. 
In his thorough study of sexuality throughout the history of Christian ethics, De Bruyn (1999:20) indicates that the idea of sexuality as inherently unholy became part of the ethics of many of the church fathers, Roman Catholic theologians during the Middle Ages, as well as Reformers and ecclesiastical movements in the period of modern church history.

The devaluation of sexuality to an inferior part of human existence is also evident in other religions and cultures. Although the sexual revolution during the 1960s and 1970s intended to bring about a liberation of sexuality from these Stoic ideas, the perception of sex as something unholy still roots deeply in modern societies. Illnesses related to sexual conduct are seen as something 'people brought unto themselves' by a sinful and impure lifestyle. Another important factor is the deep resentment of homosexual behaviour in some indigenous African cultures (Swartz 2015:2).

Ideas about sexuality that developed over centuries and are embedded in religious and cultural views and customs can rightly be regarded as an important part of the reasons for the stigmatisation of people living with HIV. Although customs are not easy to change, the issue of sexuality as a gift from God and as an essential part of life within certain relations, should be addressed by educational and religious institutions. Stigmatisation and the subsequent discrimination require a thorough re-evaluation of deeply rooted historical perceptions (Vorster 2004:232).

The truth is that stigmatisation goes against the very essence of the Christian message of love as it is evident from the life of Jesus himself. Christ himself exercised fellowship and had empathy with the marginalised and outcasts of his own society, such as the lepers, the poor, prostitutes, the sick and publicans. He preached love to the hungry, the prisoners and the sick as the practical way to serve God (Mt 25:31-46). The Christian message of reconciliation means not only to be reconciled with God, but also to fellow human beings in a relationship that annuls social elitism, bias, class differences and superiority (Viljoen 2015:9). Christian ethics should deal with the moral dilemma regarding HIV from this Biblical perspective. The principle of reconciliation can also be a moral directive in arguing the necessity of notification and disclosure.

\section{Disclosure and notification}

Venter et al. (2014:609) voice the opinion of many health workers that HIV infection should be brought out of the closet, that it should be made a notifiable disease, that it should be vigorously pursued by large-scale if not universal testing, and that infected persons should be readily identifiable. However, the reality of cultural beliefs about informed consent in the developing nations inhibits HIV patients from disclosing their status (Mystakidou et al. 2009:48).

Since 2001, testing for HIV may only be under the following circumstances in South Africa (Oosthuizen 2001:446):

- with individual request and the informed consent of the individual
- on the recommendation of a medical doctor that such testing is clinically indicated, and with the consent of the patient

- as part of HIV testing for research purposes, with consent of the individual

- as part of the screening of blood donations

- as part of unlinked and anonymous testing for epidemiological purposes, with informed consent

- where an existing blood sample is available, and an emergency situation necessitates testing the source patient's blood

- where statutory provisions or other legal authorisation exists for testing without informed consent

- proxy consent when the individual is unable to give consent

- routine testing to protect a health worker is impermissible, as well as HIV testing of an employee in the workplace.

It is clear that the HIV patient cannot be forced to disclose their status, not even to their partner. This current state of affairs raises immense questions such as: What about the health of the uninformed partner, and what about the interest of the health worker? There is a moral conflict between the right to privacy on the one hand and the right to health and information on the other hand. The same problem emerges when the issue of obligatory notification is discussed (Vorster 2004:234).

A second question is whether these rules can be enforced. One example can be mentioned to validate this question. The AIDS Law Project complained to the Public Protector that the Health Professions Council of South Africa (HPCSA) is failing in its duty to ensure that its members respect the human rights of people living with HIV. The result was that not a single doctor among 28 cases referred to the HPCSA involving alleged illegal HIV testing and subsequent illegal status disclosure, has been found guilty of unprofessional conduct (Bateman 2001:283).

The question may be asked whether the declaration of HIV as a notifiable disease will promote the treatment and subsequent prevention of AIDS? The valid list of notifiable diseases in South Africa as published on the South African Society of Travel Medicine (SASTM) website ${ }^{1}$ are the following: acute flaccid paralysis, acute rheumatic fever, anthrax, brucellosis, cholera, congenital syphilis, diphtheria, food poisoning (outbreaks of more than four persons), Haemophilus influenza type $\mathrm{b}(\mathrm{Hib})$, haemorrhagic fevers of Africa (Congo fever, dengue fever, Ebola fever, lassa fever, marburg fever, Rift Valley fever), lead poisoning, legionellosis, leprosy, malaria, measles (rubella), meningococcal infections, paratyphoid fever, plague, poliomyelitis, rabies (specify whether human case or human contact), smallpox and any smallpox-like disease-excluding chickenpox, tetanus, tetanus neonatorum, tracnoma, tuberculosis, typhoid fever, typhus fever (epidemic louse-borne typhus fever, endemic flea-borne typhus fever), viral hepatitis A, B, non-A, non-B and undifferentiated, whooping cough and yellow fever.

1.Viewed 10 November 2015, from http://www.sastm.org.za/Home/Diseasenotification 
The South African Government has considered declaring HIV or AIDS in the past. On 23 April 1999, the Minister of Health decided to make HIV or AIDS a notifiable disease and the decision was published in the Government Gazette. ${ }^{2}$ The changes to health regulations, to be promulgated in three months' time, would compel health-care workers to disclose the status of people living with HIV to government officials, health-care workers involved with the patient and the patient's immediate family. Health-care workers widely supported the new measures, but AIDS activists claimed that, because of the high level of stigmatisation, it would drive the epidemic underground and would increase the country's infection rate. It would also abrogate the principles of confidentiality and anti-discrimination endorsed by the Constitution and the National AIDS plan (Oosthuizen 2001:445). The decision of the Government was then withdrawn.

\section{Ethical perspectives on disclosure and notification}

The problems regarding disclosure and notification centre around one particular question, namely: What is more important - the rights of the individual or the health of the community? South Africa has a strict policy in this regard, namely to protect the privacy of the individual. The right to privacy is a fundamental right enshrined in the chapter on fundamental rights (Article 13) of the South African Constitution. This fundamental right is used in the protection of HIV patients.

The question may be asked why this principle is not used in the case of the other notifiable diseases? The obvious answer is the fact that HIV patients are stigmatised by the community. This situation proves that the government has a pragmatic approach that will lead nowhere. When the privacy of the individual overrides the interests of the community, then the right to privacy should be limited as in the case of the sufferers of all the other notifiable diseases. This right to privacy cannot be interpreted and applied in an absolute sense (Neethling \& Potgieter 1994:705). To shed light on this dilemma, the moral conflict between the various fundamental rights must be solved.

In this case, a consequentialist approach is useful, which entails that the end must be good. The question should be asked: 'What is the purpose of disclosure and notification?' The purpose is clearly to curb the spread of HIV or AIDS and to protect people from being infected. Furthermore, the information gained can be used for better and more effective treatment. More information and transparency could be beneficial to the struggle against stigmatisation and discrimination. On the other hand, it has become clear that the secrecy surrounding HIV infection obstructs the forming of a new social construction of HIV where the infection is not seen as a plague, but as another social problem man has to deal with (Vorster 2004:235).

2.GN R485 of 23 April 1999.
An alternative approach which might be useful is a deontological perspective which states that the deed must be motivated by love. In this context, Christian love will have two focal points. On the one hand the HIV patient must be protected against all forms of discrimination. On the other hand, the community must be protected against the rapid spread of HIV or AIDS. Disclosure and notification can achieve both if handled correctly. In South Africa, AIDS is currently perceived as an 'enemy in the dark' surrounded by false perceptions, suspicion and distrust. As in the case of, for example, tuberculosis, notification can cultivate a spirit of acceptance and an urge to deal with the real problem.

A second principle flowing from a deontological approach is the attitude that a Christian must be the image of the attitude of Christ. In Philippians 2:5, the Bible instructs Christians to act according to the attitude of Christ. The main characteristic of this attitude is self-sacrifice. Christ sacrificed himself and his whole life was a life of stewardship. According to this instruction the life of the Christian should also be a life of deputyship. This deputyship manifests itself in the complete surrender of one's own life to the other person. 'Only the selfless man lives responsibly, and this means that only the selfless man lives' (Bonhoeffer 1995:222). Seen from a Christian ethical point of view, the interest of the community and the 'other' should have preference. This principle can be derived from the self-sacrificial love of Christ and the calling of Christians to love according to the example of Christ. Applying this principle to HIV will mean the self-sacrifice of the individual in favour of the health of the community. The health of the community and the right to gain information should receive preference over the right of privacy of the individual.

In view of these principles, disclosure and notification should be considered. This plea for disclosure and notification supposes a revision of the current practices in South Africa.

\section{The role of churches}

A lot has been said in literature about the task of churches in an environment struggling with this pandemic. One cannot but agree with the call for the process of discernment, the offering of moral guidance, the education of people to make responsible decisions, the promotion of an environment where responsible decision making is possible and addressing the poor socio-economic factors that prevent the exercise of personal and social responsibility (World Council of Churches 1997:47-49). However, the debate about the role of the church needs to continually address the prominent ethical issues such as the disturbing factor of stigmatisation and a Christian ethical perspective on sexual conduct.

Biblical principles dictate that the church must act as the advocate for the rights of the marginalised. According to the example of Christ, Christians should identify with the HIV infected person and be their advocate for better understanding and treatment. As with other issues in the human rights debate, the church must be the promoter of a culture of 
respect and dignity for every person. Gender equality must be promoted, especially where the inferior position of women in certain societies can be ascribed to extremist interpretations of religious texts. Furthermore, Christians should define the Biblical concept of hope in a contextual sense for people who can see no brighter future. The local congregation, as a caring community, must provide a sphere of acceptance, fellowship and understanding for the people suffering from HIV.

However, this does not imply that the Church should condone promiscuity. Irresponsible sexual behaviour is largely responsible for the transmission of HIV because open and free sexual relations provide a fertile ground for the rapid spread of the infection. Regarding Africa, Nnazor and Robinson (2016:156) claim that a decline in abstinence, sexual freedom, laxity and promiscuity, unprotected sex, limited use of contraceptives, female child marriage, female child rape and violence account for a host of socio-economic problems, including unplanned or unwanted pregnancies, complications associated with unsafe abortions, childbirth to under-aged girls and sexually transmitted infections (STIs) including HIV or AIDS.

South Africa experiences an interesting clash in attitudes regarding sexual behaviour. On the one hand, people infected with HIV are stigmatised because they are seen as people who 'brought the illness upon themselves through promiscuous behaviour'. On the other hand, sexual promiscuity and free sexual relations increased at an alarming rate in recent times. The very same community stigmatising people with HIV are engaging more and more in this very liberal and irresponsible sexual pattern (Vorster 2004:237).

Posel (2003:9) presents a very interesting insight into the change of sexual behaviour in South Africa. She proclaims that although evidence of HIV or AIDS was undeniable during the 1980s, the issue of HIV or AIDS has largely been a post-Apartheid problem. The pace of the epidemic in South Africa has lagged about 15-20 years behind that of other parts of Africa. As late as 1990, the estimated prevalence of HIV infection in SA was less than $1 \%$. These figures grew dramatically more serious by the mid1990s, reaching $22.8 \%$ by 1998 (and as high as 32.5\% in some parts of KwaZulu Natal). In other words, during the Apartheid era, the spread of HIV or AIDS within South Africa remained relatively slow. Its acceleration occurred in the wake of the transition. She attributes this situation to the fact that sex has been politicised. During the Apartheid era, rigid laws controlled sexual behaviour, and liberation from the system also entails a liberation from and reaction against the old system.

Free sexual relations are part of the experience of being free. Posel (2003) continues:

In the aftermath of political liberation, and in the midst of the widespread demobilisation of political movements, sex has become a sphere - perhaps even pre-eminently the sphere - within which new-found freedoms are vigorously asserted. Popular magazines targeting the aspirant black elite, and advertising campaigns aimed at black consumers, craft the message that blackness - and the newfound freedom to be and assert a stylish blackness - is sexy; consumption is replete with desire. And for black youth - particularly women - asserting a sexualised 'freedom' may be a statement of the rupture between the Apartheid and post-Apartheid generations, as much as a symptom of the erosion of parental authority. (p. 10)

In this culture, sex is often the indispensable vehicle of consumption. In the midst of powerful hankerings for designer labels, cell phones, access to smart cars etcetera as the conditions of social status and style, transacting sex either for immediate payment or more regular financial support (in the case of an ongoing relationship) or directly for the goods themselves, is often the condition of their acquisition (Posel 2003:7).

Posel's opinion can be questioned with the argument that HIV infection is also growing in other countries in Africa where a system of Apartheid did not exist. The question could be asked whether, for example, globalisation and greater access to the internet could also have contributed to a rise in HIV infections. Whatever the case may be, Posel's indication of the new sexual patterns that have emerged over the last decade should be taken seriously in any preventive strategy.

One must also acknowledge that the new sexual patterns in South Africa cannot only be ascribed to the political liberation, but also to the influences of modern Western culture. The Western sexual revolution of the sixties and seventies of the previous century promoted a new pattern of sexual conduct. As in other countries in the Western world, promiscuity became socially acceptable and a result of a hedonistic and materialistic culture. Free sexual relations, for example, are portrayed by the entertainment industry as a normal style of living over and against the various cultural and religious patterns of the past.

The church has to address these new sexual patterns from a Christian ethical perspective. The Bible describes sexuality as a gift from God. This principle can be derived from the Biblical themes of creation and redemption in Christ. God created man and women to become 'one flesh' (Gn 2:24). The bond between man and woman is a reflection of the love of God, and this reflection should be discerned in sexuality. Therefore, sexuality is more than just the unlimited fulfilment of sexual desires. When Jesus instructs his audience not to commit adultery, he also warns against the lustful coveting that they might commit in their hearts (Mt 5:27-32). A sexual relationship should be a relationship of love, faithfulness and compassion. In this regard, McCormick and Connors (2002:155) state that 'Christians must also be committed to expressions of sexuality that are characterised by justice, respect, fidelity, mutuality and equality, and must resist every sort of sexual abuse, manipulation, violence, domination, oppression or marginalisation'.

Being a gift of God, sexuality cannot be degraded to something of a lower order. Although sin and the total depravity of humankind have blemished sexuality as well as the other human activities, sexuality in itself is not unholy. 
This gift can be practised within the parameters of the Biblical directive for sound sexuality, which is within a marital relationship.

According to van Wyk (2001:293) marriage is an institution of God (Gn 2:24; Mt 19:6) and such a relationship should be founded on love, devotion and faith (Pr 3:3-4; Ef 5:25). In Scripture marriage is meant ideally to be a living sign of God's passionate, faithful and enduring love. It is a covenant relationship and this covenant presumes the giving of oneself to another in a bond that is faithful, fruitful, exclusive and permanent. Both the Old Testament and the New Testament prescribe a sexual relationship in the safe sphere of this permanent marital relationship (Dt 22:28-29; 1 Cor 5 and $7: 9,36)$.

Marriage may take several forms in various cultures. Whatever the cultural form of a marital relation may be, the main Biblical principles remain the same, namely love, faithfulness and permanency. Churches have a special responsibility in this age to promote this Biblical idea of sexuality. In the long run, the enjoyment of sexuality in a close relation between two individuals is the best guarantee against the spread of HIV (Vorster 2004:240).

In dealing with a Christian perspective on sexual behaviour, the issue of promotion of condoms should also be addressed. Churches have rejected the slogan of 'condomise' in HIV prevention programmes in the recent past with the argument that the promotion of the use of condoms will promote sexual promiscuity. As opposed to this point of view, the World Council of Churches, (1997) called for a more pragmatic approach and came to the following conclusion:

Without blessing or encouraging promiscuity, we recognise the reality of human sexual relationships and practice and the existence of HIV in the world. Scientific evidence has demonstrated that education on positive measures of prevention and the provision of the use of condoms help to prevent the transmission of the virus and the consequent suffering and death for many of those infected. Should not the churches, in the light of these facts, recognise the use of condoms as a method of prevention of HIV? (p. 62)

Following the same line of thought, one can ask whether it will be responsible for the church to accept the reality of drug addiction and to support a call for the provision of clean needles for drug addicts? Can this issue be approached from a consequentialist point of view? Can Christian ethics make provision for such a pragmatic approach in the case of a pandemic, even when this approach runs against the main thrust of Biblical morality?

The point of departure should be the uniqueness of the testimony of the church. This testimony should be based on the truths of the revelation of God and the moral guidance of the Ten Commandments. In the field of sexual conduct the church must be obedient to the Biblical instruction of faithfulness and sexual relations only in the safe environment of a marriage, however 'marriage' may be defined in various cultures. In other words, sexuality must be confined to the close faithful relationship of two people. Within this relation, condoms for protection may be used and the church should encourage such a practice. However, a call for the indiscriminate use of condoms should not be part of the message of the church because such an approach will compromise the uniqueness of the church and the message of Christ. The same argument will apply to the call for the provision of clean needles for drug addicts.

\section{Conclusion}

The days are long gone when the life expectancy of HIVpositive people was measured in only a few years. Nowadays, HIV-positive people are living healthy, productive lives and some are even competing in strenuous sports such as ultramarathons (Barbara Kingsley 2015). Yet, even while the efficacy of treatment has improved dramatically, it remains expensive and exclusive, and therefore efforts to prevent HIV from spreading should continue unabated.

It is submitted that even the best medically based intervention measures will be in vain if the current culture of stigmatisation persists. The community must be educated to see HIV as a social problem that can be dealt with when people change their prejudices, attitudes, lifestyles, fears and perceptions.

The church of God can and will never succumb to worldly demands regarding promiscuity. The Bible is very clear that sexual relations should only be practiced within marriage, and that practices that can harm the body such as drug abuse is sin. Furthermore, Christian ethics require that the neighbour's interests are to be put above one's own interests.

Dealing with HIV in an effective and responsible way in obedience to the Word of God challenges the ethics of human rights. From a Christian perspective, it is clear that in the current crisis in South Africa, preference should be given to the health of the community and people's rights to gain information while individual rights such as privacy, liberty and security of person might be limited. Obligatory disclosure and notification will be unavoidable if the community wants to bring HIV out of the cloud of secrecy and suspicion.

The fact that churches take the Word of God and Christian morality as point of departure in HIV or AIDS intervention programmes, however, does not imply that people who transgressed religious moral teachings may be condemned. On the contrary, the church preaches Christian forgiveness, mercy and empathy as taught in, inter alia, 1 John 2 . Churches and organisations affiliated with churches should therefore be regarded as valuable partners in the fight against AIDS, for although propagating a normative lifestyle, they also preach forgiveness, mercy, love, compassion and support for people living with HIV. 


\section{Acknowledgements Competing interests}

The authors declare that they have no financial or personal relationships which may have inappropriately influenced them in writing this article.

\section{Authors' contributions}

I.J.v.d.W. was responsible for the original idea and the context of the article, and also wrote the manuscript. J.M.V. made significant conceptual contributions mainly related to the application of Christian ethics to HIV or AIDS interventions.

\section{References}

Bateman, C., 2001, 'HPCSA Aids cases under scrutiny', South African Medical Journal 91(283-284).

Beaulieu, M., Adrien, A., Potvin, L. \& Dassa, C., 2014, 'Stigmatizing attitudes towards people living with HIV/AIDS: Validation of a measurement scale', BMC Public Health 14, 1246.

Bonhoeffer, D., 1995, Ethics, Touchstone, London.

Campbell, C., 2004, 'Creating environments that support peer education: Experiences from HIV/AIDS prevention in South Africa (editorial)', Health Education 104(4), 197-200.

Campbell, C., Skovdal, M. \& Gibbs, A., 2011, 'Creating social spaces to tackle AIDSrelated stigma: Reviewing the role of church groups in Sub-Saharan Africa', AIDS and Behavior 15, 1204-1219.

Chigwedere, P. \& Essex, M., 2010, 'AIDS denialism and public health practice', AIDS and Behavior 14(2), 237-247. http://dx.doi.org/10.1007/s10461-009-9654-7

De Bruyn, P., 1999, Ethical perspectives, PU for CHE, Potchefstroom.

Eriksson, E., Lindmark, G., Haddad, B. \& Axemo, P., 2014, 'Young people, sexuality, and HIV prevention within Christian faith communities in South Africa: A cross-
sectional survey', Journal of Religion Health 53, 1662-1675. http://dx.doi. sectional survey', Journal of Religion
org/10.1007/s10943-013-9753-9757

Goodson, P., 2014, 'Questioning the HIV-AIDS hypothesis: 30 years of dissent', Frontiers in Public Health 2, 154. http://dx.doi.org/10.3389/fpubh.2014.00154

Hershey, M., 2015, 'Understanding the effects of faith: A comparison of religious and secular HIV prevention NGO's in Kenya', Journal of International Development 28 (2), 161-176.

Kalichman, S., 2009, Denying AIDS: Conspiracy theories, pseudoscience, and human tragedy, Copernicus/Springer, New York.

Lindgren, T., Schell, E., Rankin, S., Phiri, J., Fiedler, R. \& Chakanza, J., 2013, 'A response to Edzi (AIDS): Malawi faith-based organizations' impact on HIV prevention and care', Journal of the Association of Nurses in AIDS Care 24(3), 227-241.

Mash, R. \& Mash, R., 2013, 'Faithbased organisations and HIV prevention in Africa: A review', African Journal of Primary Health Care \& Family Medicine 5(1), Art. \#464, 6 pages. http://dx.doi. org/10.4102/phcfm.v5i1.464

Mavhandu-Mudzusi, A.H. \& Sandy, P.T., 2015, 'Religion related stigma and discrimination experienced by lesbian, gay, bisexual and transgender students at a South African rural-based university', Culture, Health \& Sexuality: An International Journal rural-based university, Culture, Health \& Sexuality: An International Journal for Research, Intervention

McCormick, P.T. \& Connors, R.B., 2002, Facing ethical issues, dimensions of character, choices and community, Paulist Press, New York.

Morgan, R., Green, A. \& Boesten, J., 2013, 'Aligning faith-based and national HIV/VIGS prevention responses? Factors influencing the HIV/AIDS prevention policy process and response of faith-based NGOs in Tanzania', Health Policy and Planning 29, 313-322.
Mystakidou, K., Panagiotou, I., Katsaragakis, S., Tsilika, E. \& Parpa, E., 2009, 'Ethical and practical challenges in implementing informed consent in HIV/AIDS clinical trials in developing or resource-limited countries', SAHARA-J: Journal of Social Aspects of developing or resource-limited countries', SAHARA-J: Journal of Social
HIV/AIDS 6(2), 46-57. http://dx.doi.org/10.1080/17290376.2009.9724930

Nagel, P., 2001, 'Gnosis, Gnosticism', in Encyclopedia of Christianity Online, viewed 29 July 2016, from http://dx.doi.org/10.1163/2211-2685 eco G92, First published online 2011, First print edition: ISBN: $9789004169678, \overline{20080512}$

Nattrass, N., 2010, 'Still crazy after all these years: The challenge of AIDS denialism for science', AIDS and Behavior 14(2), 248-251. http://dx.doi.org/10.1007/s10461009-9641-z

Neethling, J. \& Potgieter, J.M., 1994, 'Aspekte van die reg op privaatheid', Tydskrif vir hedendaagse Romeins-Hollandse reg 57(4), p. 703-710.

Nnazor, A.I. \& Robinson, J.P., 2016, 'Virginity rituals and national development: Harnessing a traditional virtue to address modern challenges in Africa', Mediterranean Journal of Social Sciences 7(1), S1. http://dx.doi.org/10.5901/ mjss.2016.v7n1s1p155

Oosthuizen, H., 2001, 'National policy on testing for HIV in South Africa: An urgent need', Medicine and Law 20, 435-450.

Paiva, V., Garcia, J., Rios, L.F., Santos, A.O., Terto, V. \& Munõz-Laboy, M., 2010 'Religious communities and HIV prevention: An intervention study using a human
rights-based approach', Global Public Health 5(3), 280-294. http://dx.doi.org/ rights-based approach', Global
$10.1080 / 17441691003677421$

Parmet, W.E. \& Jackson, D.E., 1997, 'No longer disabled: The legal impact of the new social construction of HIV', American Journal of Law \& Medicine 7, XXIII(1), 7-43.

Posel, D., 2003, Getting the nation talking about sex: Reflections on the politics of sexuality and nation-building in post-apartheid South Africa, Wits Institute for Social and Economic Research, University of the Witwatersrand, Johannesburg (unpublished)

Santelli, J.S., Speizer, I.S. \& Edelstein, Z.R., 2013, 'Abstinence promotion under PEPFAR: The shifting focus of HIV prevention for youth', Global Public Health: An International Journal for Research, Policy and Practice 8(1), 1-12.

Sidebe, M., 2015, 'Foreword', in Global AIDS response progress reporting 2015, UNAIDS/JC2702E, viewed 02 February 2016, from http://www.unaids.org/en/ resources/documents/2015/GARPR_2015_guidelines

Smith, E.A., Miller, J.A., Newsome, V., Sofolahan, Y.A. \& Airhihenbuwa, C.O., 2014 'Measuring HIV/AIDS-Related Stigma Across South Africa: A Versatile and Multidimensional Scale', Health Education \& Behavior Vol. 41(4), 387-391.

Statistics SA, 2015, 'Mid-year population estimates 2015', http://www.statssa.gov.za/ publications/P0302/P03022015.pdf

Swartz, O., 2015, 'Gay rights/African American rights: A common struggle for social justice', Socialism and Democracy 29(2), 1-24. http://dx.doi.org/10.1080/08854300. 2015.1034984

Trinitapoli, J. \& Weinreb, A., 2012, Religion and AIDS in Africa, Oxford University Press, New York, xii +279 pages.

UNAIDS, 2015, Global AIDS response progress reporting 2015, UNAIDS/JC2702E, viewed 16 February 2016, from http://www.unaids.org/en/resources/documents/ 2015/GARPR_2015_guidelines

Van Niekerk, J., 2003, 'Politics must move mainstream on AIDS', South African Medical Journal 93(3), 1.

Van Wyk, J.H., 2001, Etiek en eksistensie in koninkryksperspektief, Potchefstroomse Teologiese Publikasies, Potchefstroom.

Venter, W.D.F., Black, A., Allais, L. \& Richter, M., 2014, 'Should HIV be a notifiable disease? Old questions with some new arguments', South African Medical Journal 104(9), 607-609.

Viljoen, F.P., 2015, 'The double love commandment', In die Skriflig 49(1), Art. \#1869, 11 pages. $\mathrm{http}: / / \mathrm{dx}$.doi.org/10.4102/ids.v49i1.1869

Vorster, J.M., 2004, Ethical perspectives on human rights, Potchefstroom Theological Publications, Potchefstroom, South Africa.

Walker, W., 1992, A history of the Christian Church, T\&T Clark, Edinburg.

Williams, L.D., 2014, 'Understanding the relationships among HIV/AIDS-related stigma, health service utilization, and HIV prevalence and incidence in sub-Saharan Africa: A multi-level theoretical perspective', American Journal of Community Psychology 53, 146-158.

World Council of Churches, 1997, Facing AIDS, the churches' response, a WCC study document, WCC Publications, Geneva. 